\title{
Largest Reported 3 month drop in HbA1c for a Newly Diagnosed Patient with Type 2 Diabetes
}

\author{
John F Burd* and Vivianne Noetzel \\ Lysulin Inc., USA \\ Submission: June 08, 2018; Published: July 09, 2018 \\ *Corresponding author: John F Burd, PhD, Lysulin Inc., San Diego, California, USA, Email: jburd@jburd.com
}

\section{Short Communication}

Diabetes mellitus is a leading cause of morbidity and mortality worldwide [1]. The causes of type- 2 diabetes are multi-factorial, and supplements can play an important role on its' incidence, severity and management [2]. Hence studies have frequently focused on dietary components beneficial in the prevention and treatment of diabetes. Recent studies have demonstrated that numerous herbal and nutraceutical products have beneficial effects in patients by improving glucose and lipid metabolism, antioxidant status, disease progression and capillary function [3].

Lysulin $^{\text {TM }}$ is a new supplement for people with Type 2 diabetes and prediabetes and those atrisk of developing diabetes and metabolic syndrome [4]. Lysulin is a nutritional supplement tablet manufactured in the USA which contains the essential amino acid Lysine, a micronutrient Zinc and Vitamin $\mathrm{C}$ as the active ingredients, together with other standard excipients
(Lysulin Inc, San Diego, CA) (www.lysulin.com). The patent pending Lysulin formulation contains the essential amino acid, lysine, a mineral, zinc, and vitamin C. All of these ingredients have been shown in over 20 years of R\&D and clinical studies to lower blood glucose, lower glycated proteins and improve the lipid profile by lowering cholesterol and LDL and raising HDL. Daily use of Lysulin ${ }^{\text {TM }}$ may slow or halt the progression of prediabetes to diabetes and slow or halt the progression of diabetes complications by lowering protein glycation.

We wish to report the largest documented three month drop in HbA1c in a newly diagnosed patient with Type 2 diabetes. MR was diagnosed with Type 2 diabetes as a result of an HbA1c of 12.8. He immediately was prescribed $2000 \mathrm{mg}$ Metformin and $2 \mathrm{mg}$ Lisinopril a day. He also started self-treatment with 2 servings a day of Lysulin, a nutritional supplement for people with diabetes and prediabetes. The following drop in HbA1c was observed:

\begin{tabular}{|c|c|c|c|c|}
\hline Time & HbA1c & Test Method & ᄀ\% Drop from Day 0 & \% of 12.8 \\
\hline Day 0 & $12.8 \%$ & Laboratory & NA & 100 \\
\hline 4 week & $7.9 \%$ & $\mathrm{~A}^{1 \mathrm{c} N o w}$ & 4.9 & 61.7 \\
\hline 8 week & $5.80 \%$ & $\mathrm{~A}^{1 \mathrm{c}}$ Now & 7 & 45.3 \\
\hline 12 week & $5.40 \%$ & Laboratory & 7.4 & 42.1 (a 57.8\% drop) \\
\hline
\end{tabular}

As seen, a dramatic drop is HbA1c was observed after just one month and by 3 months the HbA1c had dropped from $12.8 \%$ down to $5.4 \%$. Several new double blind, placebo-controlled studies are underway and we plan to report on the finding that the drop in HbA1c can be seen is as little as 1 month following treatment with Lysulin and also that the use of continuous glucose monitoring shows improvement in glycemic control is as little as one week following the initiation of use of Lysulin (manuscript in preparation). Such observations may mean that home testing for HbA1c on a monthly basis may lead to more effective diabetes management. This report of a large drop in HbA1c is extraordinary and shows the promise of adding Lysulin to other oral diabetes medicines to achieve outstanding glycemic control.

\section{References}

1. Wild S, Roglic G, Green A, Sicree R, King H (2004) Global prevalence of diabetes: estimates for the year 2000 and projections for 2030 . Diabetes Care 27(5): 1047-1053.

2. Bantle JP, Wylie-Rosett J, Albright AL, Apovian CM, Clark NG, et al. (2008) Nutrition Recommendations and Interventions for Diabetes: a position statement of the American Diabetes Association. Diabetes Care 31(Suppl 1): S61-S78.

3. Bailey CJ, Kodack M (2011) Patient adherence to medication requirements for therapy of type 2 diabetes. Int J Clin Pract 65(3): 314-322.

4. Burd J (2018) Lysulin $^{T M}$, a new supplement for Nutritional Support for People with Diabetes and Prediabetes (those at risk of developing diabetes). Diabetes Manag 8(2): 38-40. 
Your next submission with Juniper Publishers will reach you the below assets

- Quality Editorial service

- Swift Peer Review

- Reprints availability

- E-prints Service

- Manuscript Podcast for convenient understanding

- Global attainment for your research

- Manuscript accessibility in different formats ( Pdf, E-pub, Full Text, Audio)

- Unceasing customer service

Track the below URL for one-step submission https://juniperpublishers.com/online-submission.php 